\title{
PEMBUATAN ALAT PENGUKUR TINGGI DAN BERAT BADAN BERBASIS MIKROKONTROLLER ATMEGA8
}

\author{
1) Suleman, ${ }^{2)}$ Andrian Eko Widodo, ${ }^{3)}$ Alif Qurnia Saputra \\ 1) Teknik Komputer, AMIK BSI Tegal \\ shule.851@gmail.com \\ 2) Sistem Informasi, STMIK Nusa Mandiri Jakarta \\ andrian.aeo@nusamandiri.ac.id \\ 2) Teknik Informatika, AMIK BSI Purwokerto \\ alif.sputra@gmail.com
}

\begin{abstract}
Preparation of design of height measurement and weight as determinant of one's ideal weight based on microcontroller. The process begins after a person has measured the weight around the work area of the tool then the heavy sensor will detect and activate the ultrasonic sensor for high measuring then all the results obtained values will be processed in a microcontroller to be displayed on the LCD output. Determination of the ideal weight results will be displayed in the form of sound on the speaker load to be informed on the meter. The design of a series of tools is built with hardware and software. The hardware is divided into several parts, namely, (1) Input devices consisting of heavy sensors, MTV020-SD-16P modules, ultrasonic sensors, (2) Processing devices are ATMega8 microcontrollers as control centers, (3) Output devices consisting of $L C D$ and loud speakers. While the software used is BASCOM AVR, eXtreme Burner AVR, and diptrace. The software is to enter the program into the ATMega8 microcontroller as a set of commands that have been designed. The program used is using BASCOM programming language (Basic Compiler).
\end{abstract}

Keywords: Sensor Weight, Senor Ultrasonic, MTV020-SD-16P module, Microcontroller, Atmega8

Abstrak - Pembuatan rancangan alat pengukuran tinggi dan berat badan sebagai penentu berat ideal seseorang berbasis mikrokontroler. Proses dimulai setelah seseorang melakukan pengukuran berat badan di sekitar area kerja alat maka sensor berat otomatasi akan mendeteksi dan mengaktifkan sensor ultrasonic untuk ukur tinggi kemudian semua hasil nilai yang didapat akan diproses dalam mikrokontroler untuk ditampilkan pada output LCD. Penentuan hasil berat ideal tersebut akan ditampilkan berupa suara pada load speaker untuk diinformasikan pada pengukurnya. Perancangan rangkaian alat dibangun dengan perangkat keras dan perangkat lunak. Perangkat keras terbagi menjadi beberapa bagian yaitu, (1) Perangkat input yang terdiri dari sensor berat, modul MTV020-SD16P, sensor ultrasonik, (2) Perangkat pemroses yaitu mikrokontroler ATMega8 sebagai pusat pengendali alat, (3) Perangkat output yang terdiri dari LCD dan loud speaker. Sedangkan perangkat lunak yang digunakan adalah BASCOM AVR, eXtreme Burner AVR, dan diptrace. Perangkat lunak tersebut untuk memasukan program ke dalam mikrokontroler ATMega8 sebagai kumpulan perintah yang telah dirancang. Program yang digunakan menggunakan bahasa pemrograman BASCOM (Basic Compiler).

Kata Kunci: Sensor Berat, Senor Ultrasonik, modul MTV020-SD-16P, Mikrokontroller, Atmega8

\section{A. PENDAHULUAN}

Saat ini banyak diantara dari kita yang sedang menggandrungi atau menyenangi dalam hal pengembangan kemajuan teknologi dan ilmu pengetahuan. Manusia menyatukan kedua hal tersebut yaitu teknologi dan ilmu pengetahuan untuk membuat suatu aplikasi/alat yang dapat membantu kinerja bagi kehidupan manusia. Salah satu alat yang telah dibuat adalah alat pengukuran, dengan alat ini manusia mampu mengetahui besarnya suatu nilai yang nantinya akan sangat berfungsi dalam perhitungan dikehidupan sehari - hari. Pengukuran yang sering dilakukan pada manusia adalah pengukuran tinggi badan dan berat badan.

Pengukuran tinggi badan biasanya dilakukan seseorang dalam instansi atau lembaga pemerintah maupun swasta/perusahaan untuk keperluan tertentu. Pengukuran tersebut dilakukan biasanya untuk keperluan seperti perekrutan karyawan atau SDM (Sumber Daya Manusia). Juga, bisa dan biasa digunakan seseorang untuk penentuan baik atau tidaknya GIZI, yaitu dengan membandingkan berat badan (BB) terhadap tinggi badan (TB) yang bersangkutan.

Padatnya kegiatan, kita kadang mulai melupakan kesehatan badan dari mulai 
terlambat makan ataupun makan secara berlebihan. Orang akan mulai mengeluh setelah badannya tidak sesuai dengan keinginannya. Penyebutan "Gemuk" atau " Kurus" merupakan istilah yang sering digunakan di masyarakat untuk mengklasifikasikan seseorang yang memilki badan tidak sesuai (tidak ideal).

Sesungguhnya badan ideal seseorang dapat dicapai dengan mudah, namun harus melalui beberapa tahapan. Untuk menentukan berat ideal dibutuhkan pengukuran berat dan tinggi badan seseorang. Dengan alat pengukuran yang telah ada, pengukuran kurang efisien baik dari segi waktu maupun penggunaan. Seperti mengukur tinggi badan seseorang, pengukuran tersebut setidaknya harus dibantu dengan orang lain untuk melihat ukuran yang tertera pada alat ukur.

Semua permasalahan dan kekurangan yang telah dijelaskan sebelumnya, maka penulis tertarik untuk mencoba mengatasi permasalahan tersebut dengan membuat alat "Pembuatan Alat Pengukur Tinggi Dan Berat Badan Berbasis Mikrokontroler ATMega8 yang diharapkan dapat membantu menyelesaikan permasalahan tersebut. Pada latar belakang tersebut dapat ditarik beberapa permasalahan, antara lain:

1. Adanya sikap acuh sebagian masyarakat terhadap kesehatan (keidealan) tubuh yang dapat menyebabakan komplikasi penyakit berbahaya, sehingga diperlukan alat yang mudah dan praktis dalam memantau kesehatan (keidealan) tubuh.

2. Banyaknya lembaga yang melakukan pengukuran tinggi dan berat badan dalam perekrutan tenaga kerja jika menggunakan cara manual tentu saja membutuhkan waktu dan tenaga yang cukup banyak, sehingga diperlukannya alat yang cepat dan akurat dalam pengukuran tersebut.

Berdasarkan hal-hal diatas, maka penelitian dibatasi dalam perancangan perangkat lunak dan perangkat keras. Alat pengukuran tinggi dan berat badan menggunakan sensor load cell sebagai pendeteksi berat badan seseorang dan sensor ultrasonik untuk mendapatakan nilai tinggi badan seseorang. Sedangkan untuk hasil tampilanya akan menggunakan LCD dan keluaran suaranya menggunakan loud speaker.

\section{B. TINJAUAN PUSTAKA}

BMI (Body Mass Index) atau dalam bahasa Indonesia disebut Index Masa Tubuh (IMT) adalah suatu pengukuran yang menunjukkan hubungan antara berat badan dan tinggi badan. Atau suatu ukuran untuk menilai "berat terhadap tinggi" badan dalam kategori (kekurangan berat badan), (kelebihan berat badan) dan Obesitas (kegemukan).

Indek massa tubuh memberiakn indikator tentang kegemukan tubuh dan juga digunakan untuk penyaringan kategori berat badan seseorang.

Berikut ini adalah tabel klasifikasi BMI berdasarkan umur yang penulis kutip berdasarkan National Research Council (NRC)

Tabel 1. Klasifikasi menurut NRC

\begin{tabular}{|c|c|c|}
\hline NO & UMUR & BMI \\
\hline 1 & $19-24$ tahun & $19-24$ \\
\hline 2 & $25-34$ tahun & $20-25$ \\
\hline 3 & $35-44$ tahun & $21-26$ \\
\hline 4 & $45-54$ tahun & $22-27$ \\
\hline 5 & $55-64$ tahun & $23-28$ \\
\hline 6 & Lebih dari 65 tahun & $24-29$ \\
\hline
\end{tabular}

Dengan pendeteksian dini dan mengerti apa itu BMI, kita dapat mengetahui berat badan dengan pola dan gaya hidup sehat sehingga gangguan kesehatan atau penyakit yang berhubungan dengan berat badan dapat kita hindari. Atau dalam bidang kesehatan, BMI digunakan oleh Dokter untuk menilai status berat badan seseorang berkaitan dengan resiko masalah kesehatan tertentu.

Rumus untuk menghitung BMI, yaitu dengan membagi berat badan dalam kilogram dengan kuadrat dari tinggi badan dalam meter $\left(\mathrm{kg} / \mathrm{m}^{2}\right)$.

$$
\mathrm{BMI}=\frac{\operatorname{BERAT}(\mathrm{Kg})}{\operatorname{TINGGI}(\mathrm{m})^{2}}
$$

Nantinya hasil dari BMI tersebut dapat dicocokkan pada Tabel Klasifikasi Internasional yang sudah disepakati oleh WHO (World Health Organization) yaitu sebagai berikut :

Tabel 2. Klasifikasi BMI dari WHO

\begin{tabular}{c|l}
\hline \multicolumn{1}{c|}{ KLASIFIKASI } & \multicolumn{1}{c}{$\begin{array}{c}\text { BMI }\left(\mathrm{Kg} / \mathrm{m}^{2}\right) \\
\text { Principal cut-off points }\end{array}$} \\
\hline UNDERWEIGHT & $<18.50$ \\
\hline Severe thinness & $<16.00$ \\
\hline Moderate thinness & $16.00-16.99$ \\
\hline Mild thinness & $17.00-18.49$ \\
\hline \hline NORMAL & $18.50-24.99$ \\
\hline \hline OVERWEIGHT & $\geq 25.00$ \\
\hline Pre-obesitas & $25.00-29.99$ \\
\hline \hline OBESITAS & $\geq 30.00$ \\
\hline Obesitas KlasI & $30.00-34.99$ \\
\hline Obesitas Klas II & $35.00-39.99$ \\
\hline Obesitas Klas III & $\geq 40.00$ \\
\hline \hline
\end{tabular}




\section{METODE PENELITIAN}

Dalam perancangan alat, dapat disusun menjadi sebuah blok diagram sebagai berikut:

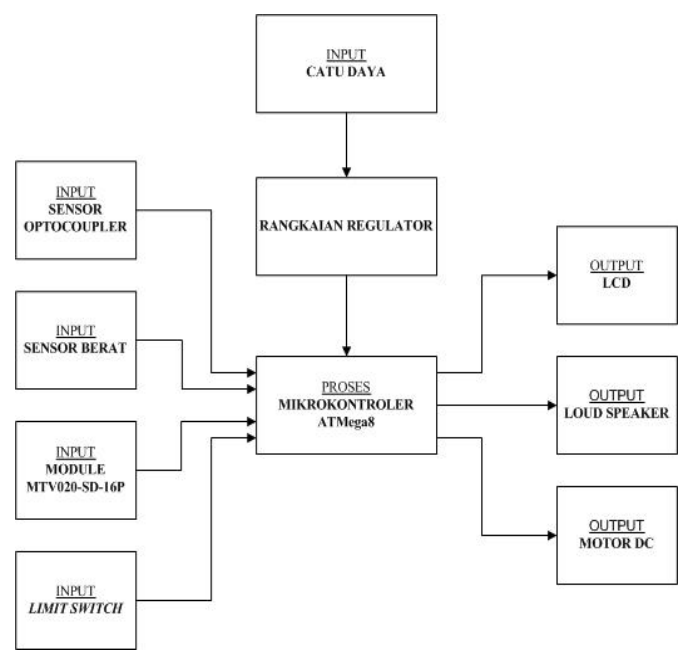

Gambar 1. Blok diagram

Rangkaian Alat Pengukur Tinggi dan Berat Badan Berbasis Mikrokontroler ATMega8

Blok diagram tersebut tersusun atas beberapa bagian skema sistem yaitu:

\section{Input}

Komponen input ini merupakan komponen masukan yang akan diproses. Komponen komponen tersebut terdiri dari :

a) Catu Daya

Catu daya adalah suatu sumber pensupply kebutuhan sumber listrik pada rangkaian, baik baterai maupun Arus PLN.

b) Rangkaian Regulator

Rangkaian Regulator merupakan rangkaian yang difungsikan untuk mendapatkan tegangan yang sesuai dengan mikrokontroler. Rangkaian regulator yang digunakan pada alat ini yaitu LM7805 yang mampu memberi keluaran sebesar 5 volt.

c) Sensor Ultrasonik

Sensor Ultrasonik berfungsi untuk melakukan pengukuran tinggi objek (manusia) dengan melakukan pengiriman gelombang dan memantulkan ke objek kemudian dipantulkan kembali ke sensor. Lama gelombang mulai dikirim hingga diterima kembali oleh sensor merupakan data yang akan menentukan jarak antara sensor dengan objek.

d) Sensor Berat

Sensor berat berfungsi untuk menentukan berat badan seseorang dan mengaktifkan mekanisme pengukuran tinggi badan.
Load cell yang digunakan memiliki spesifikasi sebagai berikut :

1) Capacity : $2 \mathrm{~kg}$

2) Operating Temperature Range: -20 $60 \mathrm{C}$

3) Recommended operating voltage: 3 to 12 VDC.

4) Maximum operating voltage: $15 \mathrm{VDC}$

5) Material: Aluminium alloy

6) Cable :0.825 cm

e) Module MTV020-SD-16P

Module MTV020-SD-16P berfungsi untuk menampung suara - suara yang nantinya akan dikeluarkan pada loud speaker.

\section{Proses}

Proses merupakan komponen utama yang berfungsi sebagai pengelola data yang diterima dari masukan (input) yang kemudian akan menghasilkan keluaran (Output). Dalam proses ini penulis menggunakan mikrokontroler ATMega8.

\section{Output}

Output merupakan keluaran dari semua proses yang telah dijalankan. Output yang dihasilkan yaitu :

a) LCD (Liquid Cristal Display)

LCD berfungsi untuk menampilkan hasil pengukuran berat dan tinggi badan seseorang

b) Loud speaker

Loud speaker berfungsi untuk memberi keluaran berat ideal atau tidak ideal berupa suara.

\section{Skema rangkaian Alat}

Penjelasan skema rangkaian alat sebagai berikut:

Untuk mensimulasikan proses pengukuran tinggi dan berat badan, letakkan benda simulasi (manusia) di area jangkauan alat untuk diukur. Saat pengukuran dilakukan, sensor berat menangkap objek tersebut untuk mendapat data pengukuran berat dan sekaligus mengaktifkan sensor ultrasonik yang nantinya akan mengukur tinggi badan dengan sendirinya untuk dapat memperoleh data pengukuran tinggi. Untuk mendapatkan nilai pengukuran tinggi badan, sensor ultrasonik diletakkan pada ketinggian yang telah ditetapkan.

Ketika sensor aktif maka sensor akan mengirimkan gelombang ke objek (manusia) kemudian dipantulkan kembali menuju sensor, perhitungan lama gelombang mulai meluncur hingga kembali akan menjadi jarak selisih 
sensor dengan objek. Nilai tinggi objek (manusia) ditentukan dengan melakukan pengurangan antara tinggi letak sensor tanpa objek dengan selisih yang telah didapat tadi. Setelah hasil pengukuran sensor ultrasonik didapat maka kedua nilai tersebut diproses oleh mikrokontroler yang hasil pengukurannya akan dikeluarkan berupa tampilan LCD.

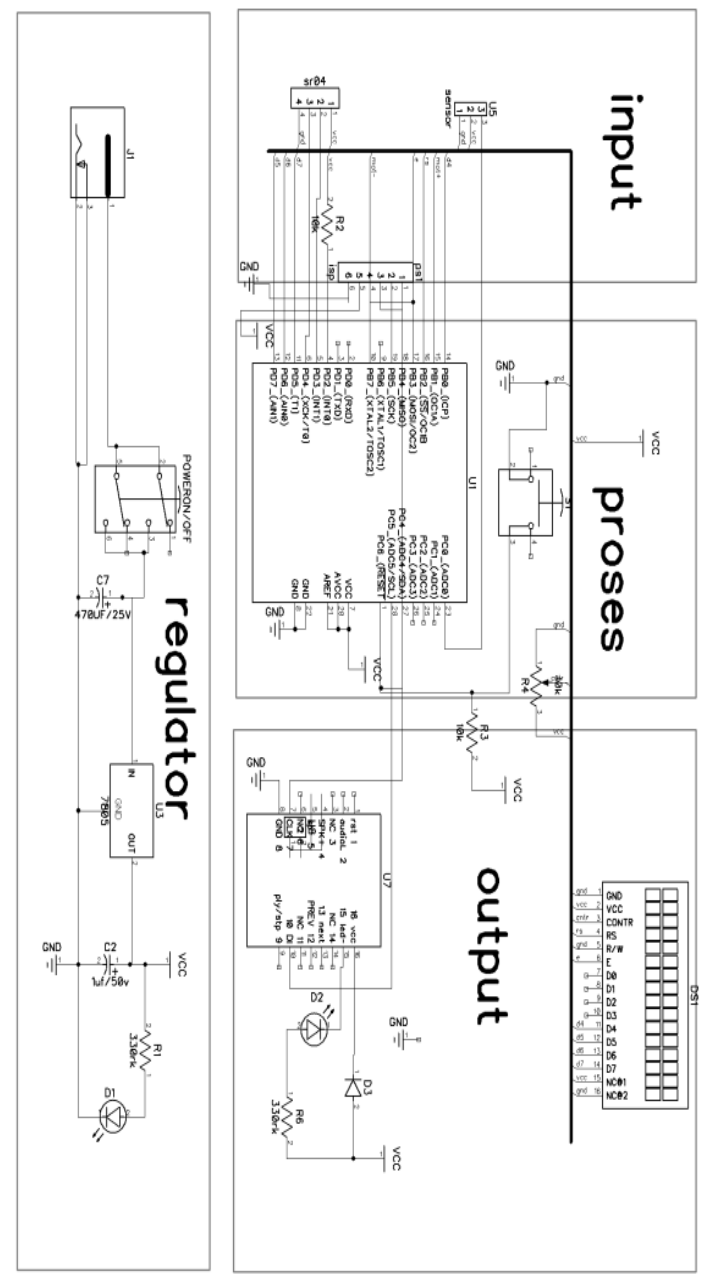

Gambar 2. Rangkaian Alat Pengukur Tinggi dan Berat Badan Berbasis Mikrokontroler ATMega8

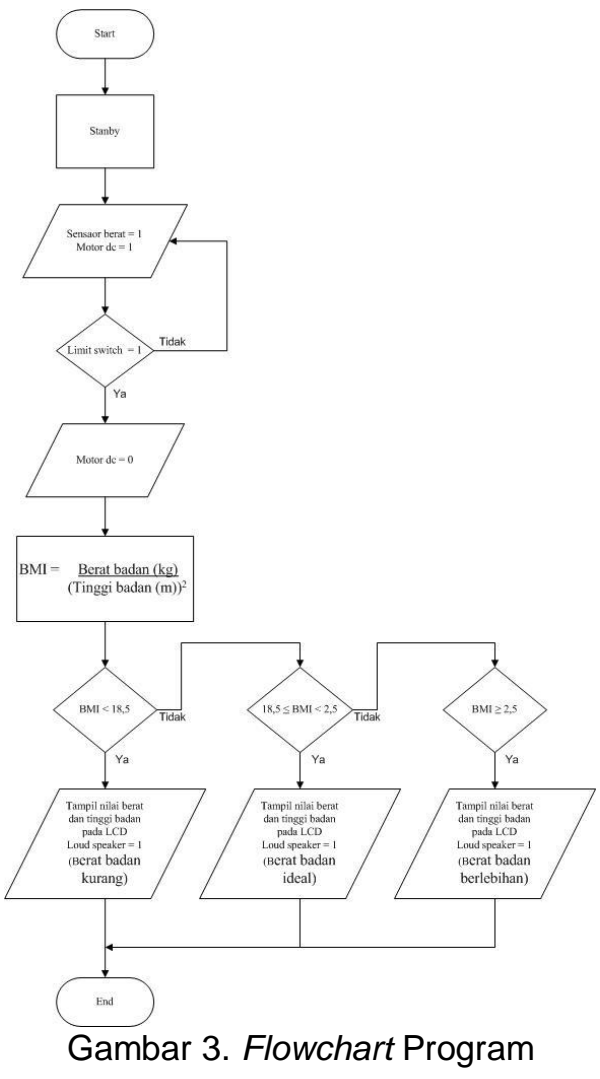

\section{HASIL DAN PEMBAHASAN}

Penulis melakukan percobaan terhadap alat ini untuk mengetahui pengaruh kerja alat dengan komponen yang digunakan dan dalam kondisi kondisi - tertentu. Percobaan pertama dilakukan agar dapat mengetahui tegangan kerja alat dan pengaruh IC 7805 pada alat.

Tabel 3.

Hasil Percobaan Mikrokontroler Tanpa Menggunakan Rangkaian Regulator

\begin{tabular}{|c|c|c|c|c|}
\hline \multirow{2}{*}{ No } & \multirow{2}{*}{ Volt } & \multirow{2}{*}{ Mikrokontroller } & \multicolumn{2}{|c|}{ Kerja Alat } \\
\hline & & & LCD & Speaker \\
\hline 1 & 3 & Tidak bekerja & Mati & Mati \\
\hline 2 & 5 & Bekerja & Menyala & Bersuara \\
\hline 3 & 6 & Panas & Menyala & Mati \\
\hline 4 & 9 & Mati & Mati & Mati \\
\hline
\end{tabular}

Keterangan:

Pada percobaan ini terlihat pada catu daya 3 volt mikrokontroler tidak dapat bekerja. Sedangkan pada tegangan 5 volt mikrokontroler dan alat dapat bekerja dengan normal, akan tetapi ketika diberi catu daya 6 volt mikrokontroler mulai panas dan lama lama kebakar sehingga menyebabkan komponen speaker dan motor mati. Sedangkan dengan tegangan 9 Volt mikrokontroler tidak mampu menahan sehingga mengakibatkan mikrokontroler menjadi panas dan terbakar kemudian mikrokontroler Mati. 
Tabel 4.

Hasil Percobaan Mikrokontroler Menggunakan Rangkaian Regulator

\begin{tabular}{|c|c|c|c|c|}
\hline \multirow{2}{*}{ No } & \multirow{2}{*}{ Volt } & \multirow{2}{*}{ Mikrokontroller } & \multicolumn{2}{|c|}{ Kerja Alat } \\
\cline { 4 - 5 } & & & LCD & Speaker \\
\hline 1 & 3 & Tidak bekerja & Mati & Mati \\
\hline 2 & 5 & Bekerja & Menyala & Bersuara \\
\hline 3 & 6 & Bekerja & Menyala & Bersuara \\
\hline 4 & 9 & Bekerja & Menyala & Bersuara \\
\hline
\end{tabular}

Dari hasil percobaan menggunakan rangkaian regulator (Tabel 4) memberikan catu daya 3 Volt mikrokontroler tidak dapat bekerja, sedangkan dengan memberi catu daya antara 5 Volt sampai dengan 9 Volt mikrokontroler dapat bekerja dengan baik, karena rangkaian regulator bekerja dengan baik menurunkan tegangan.

Dari hasil percobaan Tabel 3 dan Tabel 4 maka dapat disimpulkan bahwa pemberian catu sangat berpengaruh pada kerja mikrokontroler sehingga bisa menjadi bahan pertimbangan untuk menentukan catu daya yang ideal dalam proyek pembuatan alat berbasis mikrokontroler.

Percobaan selanjutnya penulis mengamati hasil pembacaan sensor yang ada dengan pengukuran yang sudah ditetapkan. Percobaan ini untuk mendapakan nilai konversi pembacaan dari pembacaan sensor dengan pembacaan nilai dalam $\mathrm{kg}$ dan $\mathrm{cm}$ yang dibutuhkan dalam dunia nyata.

Tabel 5

Hasil Percobaan Pengukuran sensor berat dengan berat yang sudah pasti

\begin{tabular}{|c|c|c|c|c|}
\hline \multirow{2}{*}{ No } & \multirow{2}{*}{ Nama objek } & \multicolumn{2}{|c|}{ Berat (gram) } & Selisih Berat \\
\cline { 3 - 4 } & Alat & nyata & (gram) \\
\hline 1 & Tempat lem + isi & 7 & 7,23 & 0,23 \\
\hline 2 & $\begin{array}{c}\text { Tempat obeng + } \\
\text { isi }\end{array}$ & 14 & 14,36 & 0,36 \\
\hline 3 & Tmpat gatsby + isi & 12 & 12,26 & 0,26 \\
\hline
\end{tabular}

Setelah melakukan percobaan diatas penulis telah mendapat nilai konversi yang dibutuhkan, tetapi karena alat ini merupakan alat yang memiliki tingkat kestabilan tidak terlalu tinggi maka penulis menguji alat tersebut dengan objek yang sebenarnya untuk melakukan pengukuran kembali.
Tabel 6.

Hasil Percobaan pengukuran berat untuk mengetahui tingkat kesalahan

\begin{tabular}{|c|c|c|c|c|}
\hline $\begin{array}{c}\text { Nama } \\
\text { Objek }\end{array}$ & Berat & Tinggi & LCD & $\begin{array}{c}\text { Loud } \\
\text { Speaker }\end{array}$ \\
\hline $\begin{array}{c}\text { Tempat lem } \\
+ \text { isi }\end{array}$ & 7 & 58,64 & Tampil & Bunyi \\
\hline $\begin{array}{c}\text { Tempat } \\
\text { obeng + isi }\end{array}$ & 14 & 96,59 & Tampil & Bunyi \\
\hline $\begin{array}{c}\text { Tempat } \\
\text { gatsby + isi }\end{array}$ & 12 & 31,04 & Tampil & Bunyi \\
\hline
\end{tabular}

Percobaan selajutnya adalah melakukan uji coba alat secara keseluruhan dari mulai pengukuran berat, tinggi dan pengolahan nilai hingga menghasilkan tampilan pada layar LCD dan keluaran berupa suara pada loud speaker.

Tabel 7.

Hasil percobaan pengukuran alat

\begin{tabular}{|c|c|c|c|}
\hline No & Berat (gr) & Vin (V) & ADC \\
\hline 1 & 0 & 0.43 & 22 \\
\hline 2 & 10 & 0.45 & 23 \\
\hline 3 & 20 & 0.47 & 24 \\
\hline 4 & 50 & 0.53 & 27 \\
\hline 5 & 100 & 0.61 & 31 \\
\hline 6 & 200 & 0.82 & 42 \\
\hline 7 & 500 & 1.50 & 77 \\
\hline
\end{tabular}

\section{E. KESIMPULAN}

Setelah pembuatan Alat Pengukur Tinggi dan Berat Badan Berbasis Mikrokontroler ATMega8 ini diselesaikan, penulis dapat menyimpulkan sebagai berikut:

1. Perancangan Alat Pengukur Tinggi dan Berat Badan Berbasis Mikrokontroler ATMega8 dengan Output LCD dapat berjalan sesuai konsep dan rancangan awal penulis.

2. Alat yang penulis rancang ini dapat mengukur tinggi dan berat badan seseorang secara cepat dan akurat.

3. Mekanisme pengukuran tinggi badan akan berjalan setelah objek (manusia) terdeksi oleh sensor berat (pengukuran berat).

4. LCD dapat menampilkan dengan jelas pembacaan nilai yang telah didapat pada tegangan 5 volt.

5. Keluaran yang dihasilkan loud speaker berupa suara sesuai dengan instruksi program yang telah dimasukan

\section{DAFTAR PUSTAKA}

[1] Istiyanto, Jazi Eko. 2014, Pengantar Elektronika \& Instrumenstasi Pendekatan 
Project Arduino \& Android. Yogyakarta: CV Andi Offset

[2] Jatmika, Yusep Nur. 2011. Cara Mudah Merakit Robot untuk Pemula. Yogyakarta: FlashBooks.

[3] M.H, Zaki. 2005, Cara Mudah Belajar Merangkai Elektronika Dasar. Yogyakarta: ABSOLUT

[4] NRC (National Research Council). (2000). National Science Education Standards. Washington DC: The National Academic of Sciences

[5] Prasetyono, Dwi Sunar. 2011. Belajar Cepat Sistim Cepat Elektronika. Yogyakarta: ABSOLUT.

[6] Setiawan, afrie. 2010. 20 Aplikasi Mikrokontroler ATMega 8535 dan ATMega 16 Menggunakan BASCOMAVR. Yogyakarta: CV Andi Offset

[7] Suyadhi, T.D.S. 2010. Buku Pintar Robotika Bagaimana Merancang \& Membuat Robot Sendiri. Yogyakarta: CV Andi Offset

[8] Wahyudin, Didin, 2007, Belajar Mudah Mikrokontroller AT 89552 dengan bahasa Basic Menggunakan BASCOM-8051, C.V Andi Offset, Yogyakarta.

[9] Winarno dan Deni Arifianto. 2011. Bikin Robot Itu Gampang. Surabaya: PT. Kawan Pustaka

[10] Winoto, Ardi. 2008. Mikrokontroler AVR ATMega8/16/32/8535 dan Pemrogramannya dengan bahasa $\mathrm{C}$ pada WinAVR. Bandung: Informatika

[11] http://www.atmel.com/images/atmel-24868-bit-avr-microcontrolleratmega8___datasheet.pdf

[12] http://doktersehat.com/menghitung-beratideal-kalkulator-bmi/

[13] http://www.electroschematics.com/9529/at mega8-basic-input-output-interfacing-1/

[14] https://www.iso.org/obp/ui/\#iso:std:iso:tr:1 1548:-1:ed-1:v1:en (1 Juni 2015).

[15] http://medicastore.com/penyakit/757/Men ghitung_Body_Mass_Index_BMI.html

[16] http://teknikelektronika.com/fungsipengertian-speaker-prinsip-kerja-speaker/

[17] http://www.who.int/publications/en/

[18] http://www.microchip.com/wwwproducts/e $\mathrm{n} /$ ATmega8 